\title{
The Differences in Learning Outcomes of Geography Students Using Rotation Models
}

\author{
Sukma Perdana Prasetya \\ Department of Geography Education \\ Faculty of Social Sciences and Law \\ State University of Surabaya \\ Surabaya, Indonesia \\ Corresponding email:sukmaperdana@unesa.ac.id
}

\begin{abstract}
This study aims to examine differences in learning outcomes between students who are learning with a variety of strategies to implement the rotation models. This study uses a $1 \mathrm{x}$ 3 factorial design. The subject of this study is students of Geography education, State University of Surabaya. The research subject is student class of 2015 consists of classes A (32 students) applies the rotation model 1 (group work - e-learning - lectures), class B (31 students) applies the rotation model 2 (e-learning lectures - group work), class C (32 students) applies the rotation model 3 (lecture- group work - e-learning). Learning outcomes data collected by the achievement test in narrative form. The collected data were statistically processed using the techniques of analysis of variance (one-way ANOVA) using a significance level of 0.05 . The results showed there were significant differences in learning outcomes between the student's group who apply strategies variety of the rotation model $(F=14.150 ; p=0.000)$. Results of average calculation of model rotation 1 (mean:88) is better than rotation model 2 (mean:83) and rotation model 3 (mean 76).
\end{abstract}

Keywords-Learning Outcomes, Rotation model

\section{INTRODUCTION}

Advances in information technology are so rapid influential in shifting activities from learning outside-guided be selfguided. The progress of information technology infrastructure accompanied with the ease of internet access which makes $e$ learning is increasingly popular in education. According to Miarso (2004), use of e-learning can never be separated from learning that utilizes internet access. Information learning materials using the internet so completely, so it affects the task of the teacher in the learning process. Advance the learning process dominated by the role of the teacher or the era of teacher,is now teaching and learning process is dominated by the teacher and the book (the era of teacher and books), and future teaching and learning processes are dominated by teachers, books, and information technology (the era of teacher, books, and information technology).

One type from e-learning that has been developed is blended learning. Blended learning is the most effective learning always involves mixing the use of a variety of different strategies to optimize the development of the knowledge and skills of learners. A Good learner will always use more than one strategy in their teaching. A good program of learning is to combine lectures, seminars, group projects, placements and so on to offer a variety of opportunities to learn differently (D.Marsh, 2012). A growing number of higher education institutions recently encourage faculty to use online learning environments to support classroom activities or to overcome the limitations of face-to-face learning environments (A.woolfolk, 2009).

Reigeluth (1983) noted the importance of variation strategy in learning"we are not just interested in single strategy components and isolated principles of instruction. What Instructional designers and teachers need to know is what a complete set of components strategy has a better result (for desired on outcomes)".

Based the statement Regeluth this suggests that one strategy alone is not enough to get better learning outcomes. To achieve the desired outcomes learners or learning designers must use the set (set) components of the strategy. Further, Reigeluth (1987) argued that the collection of components of the strategy include: a series of facts related content ideas, use overview (overview) and a summary, the use of examples, the use of the practice, and the use of various ways to motivate learners.

Jacobsen (2009), argues that there is no one strategy better learning than other learning strategies. Learners need to master and can implement learning strategies, in order to achieve the learning objectives are very diverse and learning environment that characterized the school at present. Learning strategies in which learners act as a facilitator, to allow learners to take a more active part in the learning process so that learners were able to construct own knowledge. Learners as facilitators provide an opportunity for learners to optimize the abilities to solve problems by using strategies centered on learners, where learners have freedom and greater autonomy. Moore (2005), suggests the need for learners in designing innovative learning through the implementation of strategies that involve more active involvement of learners.

The learning strategy that can incorporate a wide variety of learning strategies is blended learning with rotation models. Rotation is implementation common models of blended learning. Learning models divided rotation for 90 hours of lessons. For example, in small groups of learners, distance 
learning interval divided by each method are distinguished 30 minutes. If the rotation model performed for 120 minutes, then the interval distance of each method are distinguished 40 minutes.

Rotation models provide opportunities for learners of time and space to work with small groups or individual to achieve the learning objectives effectively. Besides access to comprehensive learning resources via the Internet can enhance or expand the acquired knowledge learners. Each component methods play an important role in helping learners to apply and contextualize what they learn. Rotation model is able to facilitate the learners can use the time to analyze the diversity of data and help inform practical learning (A.P.School, 2013).

The rotation model has three stages: learning face-to-face with lectures, learning collaborative practice (group work), and online learning with internet access(e-learning).All three of these stages has a variation stage can be started from 1) group work, e-learning and lectures, (rotation model 1), 2) elearning, group work, and lectures (rotation model 2), and 3) lecture, group work, and e-learning (rotation model 3).

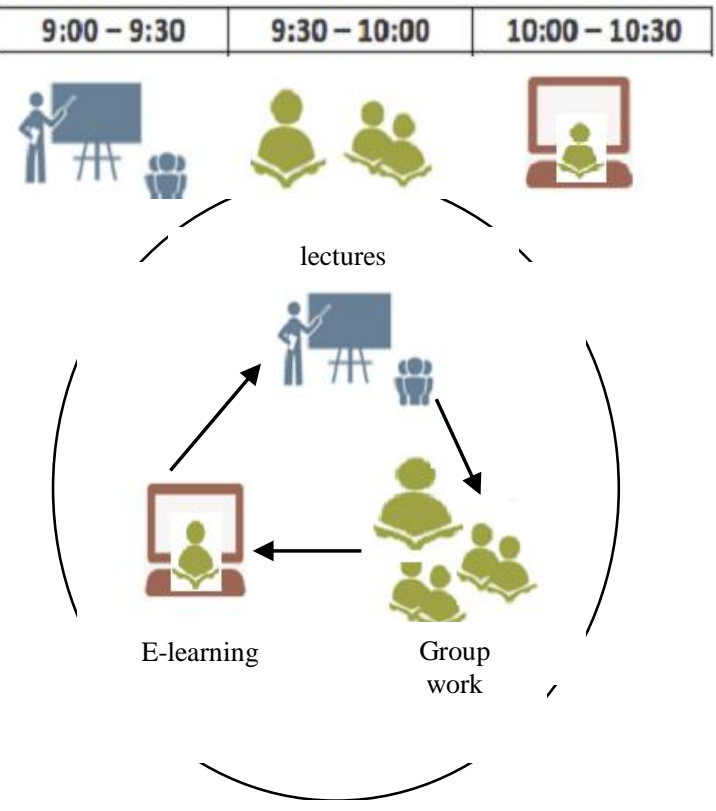

Fig. 1. Blended Learning with Rotation models (adapted from Aspire Public Scools, 2013 [8] )

This study aims to examine differences in learning outcomes between students who apply a variation learning strategy rotation models (rotation model 1, the rotation model 2 , and rotation model 3 ).

\section{METHOD}

The method chosen in this study is a quasi-experimental factorial design 1 x 3 . The study design is described as follows:
TABLE I. DESIGN RESEARCH

\begin{tabular}{|c|c|c|c|}
\hline Group & Pre-test & Treatment & Post-test \\
\hline A & $\mathrm{O}_{1}$ & $\mathrm{X}_{1}$ & $\mathrm{O}_{2}$ \\
\hline $\mathrm{B}$ & $\mathrm{O}_{1}$ & $\mathrm{X}_{2}$ & $\mathrm{O}_{2}$ \\
\hline $\mathrm{C}$ & $\mathrm{O}_{1}$ & $\mathrm{X}_{3}$ & $\mathrm{O}_{2}$ \\
\hline
\end{tabular}

Description:

$\mathrm{O}_{1}=$ Pre-test

$\mathrm{O}_{2}=$ Post-test

$\mathrm{X}_{1}$ = work group - e-learning - lectures (rotation model 1)

$\mathrm{X}_{2}$ = e-learning - lectures - group work (rotation model 2)

$\mathrm{X}_{3}=$ lecture - group work - e-learning (rotation model 3)

The variables in this study a variable independent and dependent. The independent variable was the rotation models (rotation model 1, rotation model 2, and rotation model 3 ) and the dependent variable is learning outcomes.

The research subjects include students of Geography Education, FISH, Unesa. The research subject is student class of 2015 consists of classes A (32) applying rotation model 1 (group work - e-learning - lectures), class B (31) applying rotation model 2 (e-learning - lectures - group work), class C (32) applying rotation model 3 (lecture- group work - elearning). Data analysis using one-way ANOVA to verify the hypothesis.

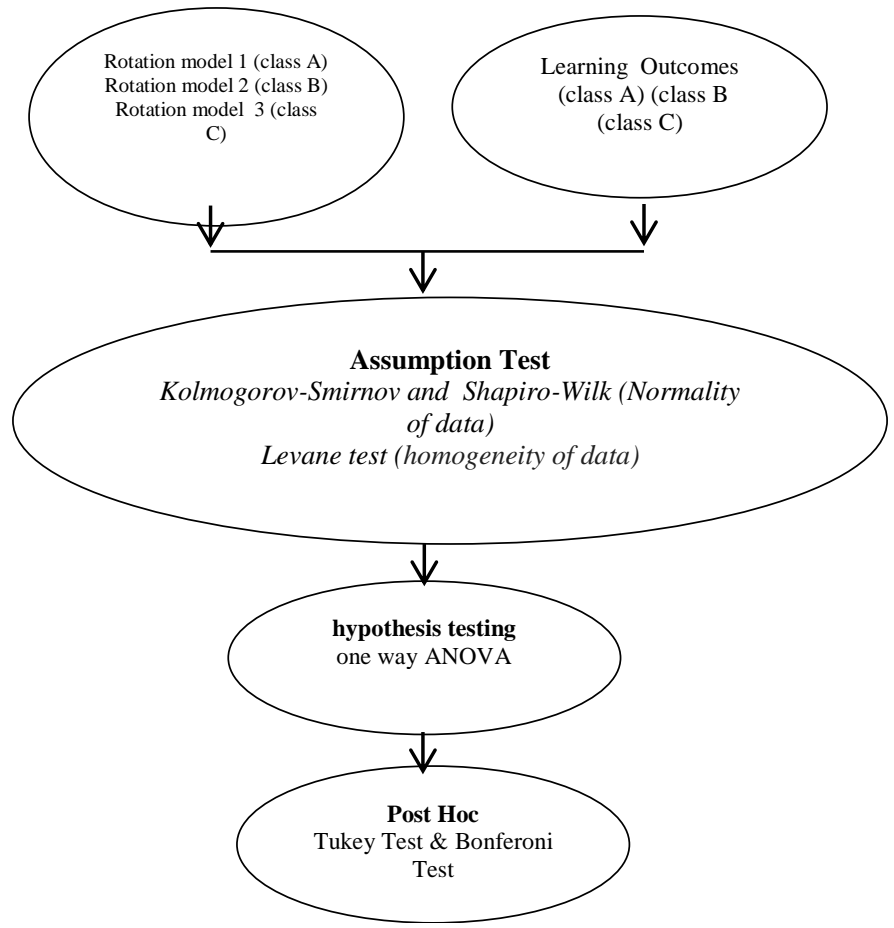

Fig. 2. The research procedure

\section{FINDING AND DISCUSSION}

Before data analyzed, first implemented assumption test of test results Significance Lillefors Correction from Kolmogorov-Smirnov and Shapiro-Wilk can be summarized as follows: (1) through the test Kolmogorov-Smirnov received for learning rotation models 1 , rotation model 2 and rotation model 3, a significance level or probability of above $0.05(\mathrm{p}=$ 
$0.200,0.091$, and 0.192), it can be concluded the distribution of the three types of rotation models is normal, (2) through the test Shapiro-Wilk received for rotation models 1, 2, and 3, a significance level or probability of above $0.05(\mathrm{p}=0.213$, 0.067 , and 0.187 ), it can be concluded third data distribution rotation model is normal.

From the calculation of learning outcomes data with SPSS, statistical counts obtained results Lavene with significance level or probability of the mean (average) is above 0.05 ( $\mathrm{p}=$ 0.491> 0.05). Similarly, if the basis of measurement is the median of the numeric data of significance is 0.312 which remains above 0.05 . So we can conclude $\mathrm{H}_{0}$ is received, so it can be interpreted that the sample variances homogeneous.

With regard to the outcome of the prerequisite tests, which test for normality and homogeneity, it can be concluded that for the test analysis of variance (ANOVA) can be done. Hypothesis testing is done by analyzing the achievement test. After calculation techniques of analysis of variance (ANOVA) one lane at a significance level of 0.05 , the data obtained as follows.

TABLE II. SUMMARY of RESULTS of ANALYSIS of VARIANCE CALCULATION TECHNIQUE ONE LINE $(\alpha=0.05)$

\begin{tabular}{|c|r|r|r|r|r|}
\hline & $\begin{array}{c}\text { Sum of } \\
\text { Squares }\end{array}$ & \multicolumn{1}{c|}{ df } & $\begin{array}{c}\text { Mean } \\
\text { Square }\end{array}$ & F & Sig. \\
\hline $\begin{array}{c}\text { Between } \\
\text { Groups }\end{array}$ & 1242.856 & 2 & 621428 & 14150 & .000 \\
\hline Within Groups & 3206.026 & 93 & 43918 & & \\
\hline \multicolumn{7}{|c|}{ Total } & 4448.882 & 95 & & & \\
\hline
\end{tabular}

Based on the calculation table of learning outcomes using ANOVA Technique of the above lines, it can be seen $\mathrm{F}_{\text {count }}$ has a value of 14.150 while the $F_{\text {table }}$ has a value of 3,122103 . Thus we can conclude $\mathrm{F}_{\text {table }}<\mathrm{F}_{\text {count }}(3.122103<14.150)$ then $\mathrm{H}_{0}$ is rejected. So the decision to use $\mathrm{H}_{1}$ is the result of learning using the learning model of rotation 1 , the model of rotation 2 and rotation model 3 is not the same (no difference) in other words the model's rotation influence on student results. To see any significant difference between learning rotation model 1 , model 2 and model 3, achievement test were then tested using Bonferroni and Tukey test.
TABLE III. POST HOC TEST LEARNING OUTCOMES USING ROTATION MODEL 1， ROTATION MODEL 2 AND ROTATION MODEL 3

Dependent Variable: Hasil learning outcomes

\begin{tabular}{|c|c|c|c|c|c|c|c|}
\hline & \multirow{2}{*}{ (I) Class } & \multirow{2}{*}{ (J) Class } & \multirow{2}{*}{$\begin{array}{c}\text { Mean } \\
\text { Differen } \\
\text { ce }(\mathbf{I}-\mathbf{J})\end{array}$} & \multirow{2}{*}{$\begin{array}{l}\text { Std. } \\
\text { Error }\end{array}$} & \multirow{2}{*}{ Sig. } & \multicolumn{2}{|c|}{$\begin{array}{c}\text { 95\% Confidence } \\
\text { Interval }\end{array}$} \\
\hline & & & & & & $\begin{array}{l}\text { Lower } \\
\text { Bound }\end{array}$ & $\begin{array}{l}\text { Upper } \\
\text { Bound }\end{array}$ \\
\hline \multirow{6}{*}{ Tukey HSD } & \multirow{2}{*}{$\begin{array}{l}\text { Rotation } \\
\text { Model } 1\end{array}$} & $\begin{array}{l}\text { Rotation } \\
\text { Model } 2\end{array}$ & $5.19231^{*}$ & 1.83802 & .017 & .7950 & 9.5897 \\
\hline & & \begin{tabular}{|l} 
Rotation \\
Model 3
\end{tabular} & $9.96795^{*}$ & 1.87592 & .000 & 5.4799 & 14.4560 \\
\hline & \multirow{2}{*}{$\begin{array}{l}\text { Rotation } \\
\text { Model } 2\end{array}$} & \begin{tabular}{|l|} 
Rotation \\
Model 1
\end{tabular} & - & 1.83802 & .017 & -9.5897 & -.7950 \\
\hline & & \begin{tabular}{|l|} 
Rotation \\
Model 3
\end{tabular} & $4.77564^{*}$ & 1.87592 & .034 & .2876 & 9.2637 \\
\hline & \multirow{2}{*}{\begin{tabular}{|l} 
Rotation \\
Model 3
\end{tabular}} & \begin{tabular}{|l|} 
Rotation \\
Model 1
\end{tabular} & $9.96795 *$ & 1.87592 & .000 & -14.4560 & -5.4799 \\
\hline & & \begin{tabular}{|l|} 
Rotation \\
Model 2
\end{tabular} & $4.77564 *$ & 1.87592 & .034 & -9.2637 & -.2876 \\
\hline \multirow{6}{*}{ Bonferroni } & \multirow{2}{*}{\begin{tabular}{|l} 
Rotation \\
Model 1
\end{tabular}} & \begin{tabular}{|l} 
Rotation \\
Model 2 \\
\end{tabular} & $5.19231^{*}$ & 1.83802 & .018 & .6884 & 9.6962 \\
\hline & & \begin{tabular}{|l} 
Rotation \\
Model 3
\end{tabular} & $9.96795^{*}$ & 1.87592 & .000 & 5.3712 & 14.5647 \\
\hline & \multirow{2}{*}{$\begin{array}{l}\text { Rotation } \\
\text { Model } 2\end{array}$} & \begin{tabular}{|l|} 
Rotation \\
Model 1
\end{tabular} & $-\overline{5.19231^{*}}$ & 1.83802 & .018 & -9.6962 & -.6884 \\
\hline & & \begin{tabular}{|l} 
Rotation \\
Model 3
\end{tabular} & $4.77564^{*}$ & 1.87592 & .039 & .1789 & 9.3724 \\
\hline & \multirow{2}{*}{\begin{tabular}{|l} 
Rotation \\
Model 3
\end{tabular}} & \begin{tabular}{|l} 
Rotation \\
Model 1
\end{tabular} & $9.96795^{*}$ & 1.87592 & .000 & -14.5647 & -5.3712 \\
\hline & & $\begin{array}{l}\text { Rotation } \\
\text { Model } 2\end{array}$ & - & 1.87592 & .039 & -9.3724 & -.1789 \\
\hline
\end{tabular}

*. The mean difference is significant at the 0.05 level.

\section{A. The Differences in Learning Outcomes of Rotation Model 1 and Rotation Model 2.}

From the calculation of Post Hoc Test data result of learning between groups of students are using the rotation model 1 and the rotation model 2 , the data obtained $\mathrm{F}=$ 5.19231; $p=0,17$. This means that there are significant differences in learning outcomes between groups of students using the rotation model study 1 with a group of students who use the learning model of rotation 2. By looking at the average value indicates that the average result of learning student groups using the rotation model study 1 by 88,88 is greater than the average student results using the rotation model of 1 is equal to 83.69. It can be concluded that in general the results of learning achieved student groups using the rotation model 1 is better than a group of students who use the rotation model 2 of learning.

\section{B. The Differences in Learning Outcomes of Rotation Model 1 and Rotation Model 3.}

From the calculation of Post Hoc Test data result of learning between groups of students are using the rotation model 1 and the rotation model 3 , the data obtained $\mathrm{F}=$ 9.96795; $p=0,00$. This means that there are significant differences in learning outcomes between groups of students using the rotation model study 1 with a group of students studying models of rotation 3. By looking at the average value indicates that the average result of learning student groups 
using the rotation model study 1 by 88,88 is greater than the average student results with the rotation model 3 is equal to 78.92. It can be concluded that in general the results of learning achieved student groups using the rotation model 1 is better than a group of students who use the rotation model 3 of learning.

\section{The Differences in Learning Outcomes of Rotation Model 2 and Rotation Model 3.}

From the calculation of Post Hoc Test data result of learning between groups of students are using the rotation model 2 and the rotation model 32 , the data obtained $\mathrm{F}=4 ; p=$ 0,034 . This means that there are significant differences in learning outcomes between groups of students using the rotation model study two groups of students studying the model of rotation 3. By looking at the average value indicates that the average result of learning student groups using the rotation model study 2 by 83,69 is greater than the average student results were studied using a model of rotation 3 is equal to 78.92. It can be concluded that in general the results of learning achieved student groups using the rotation model 2 is better than a group of students who use the rotation model 3 of learning.

Based on test results obtained above hypothesis can be concluded that in general the result of learning student groups using the rotation model 1 learning is better than learning outcomes student groups using the rotation model 2 and the results of student learning that using the rotation model 3 .

Results of a study on the rotation model 1, the rotation and the rotation model 2 model 3 there are differences in learning outcomes seen in pretest and posttest results seen from the average value. In class rotation model 1 pre-tests an average value of 43.19 and a ride after being given treatment in the form of rotation model 1 with an average post-test score of 88.88. the class rotation model 2 pretest value amounted to 43.73 later after being treated in the form of application of the rotation model 2 , the value pre-test rose to 83.69 . In class rotation model 3 gets on average pretest score of 43.13 and then after a rotation model 3 of learning gets an average value of 78.92 .

Based on the above, the entire class has increased the average value on the posttest. The third class of the class by using the rotation model 1 has the highest increase, followed by the class using the rotation model 2 , and rotation of the model 3. In the rotation model 1 (group work - e-learning lecture) shows the learning outcome the most. In this rotation model of learning begins with group work, where students are faced with solving a variety of problems.

The group work with collaborative learning has been proven in promotes learning outcomes development (K. Moore, 2005: R. Chiong \& J. Jovanovic, 2012: R. Phungsuk, 2017). Findings Phungsuk, et al, (2017) asserted that the ability of students in problem-solving through group work led to increased understanding of new students through cognitive conflict. Students were trained to search for the answer to a question on their own. Using this model, students were compelled to search for answers on their own and, thus, able to retain what they learned for a longer period of time. Findings Ismaimuza (2010) suggested that the problem-based learning with cognitive conflict strategies to improve learning outcomes, especially related to the understanding of the concept. Woolfolk (2009) suggests that when someone builds a science, it is to establish a balance higher knowledge required assimilation, namely contact or effective cognitive conflict between the old concept of a new reality. Cognitive structures that humans have always interacted with their environment by means of assimilation and accommodation. If assimilation and accommodation occur freely and without conflict, then the cognitive structure said to be in a state of balance (equilibrium) with its environment. However, if a conflict occurs then the person is in a state of balance (disequilibrium). This happens because when one is in a state of disequilibrium, he will respond to the situation, and try to remember, empowering concept that has to find a new equilibrium with its environment.

Conflicts cognitive can arise in situations of problems cited in learning so that there is disagreement on student self, Through strategy problem-based learning students are faced with real problems or issues that are simulated, the problem is if it does not correspond to the cognitive structure of students may lead to conflict, then students work together in groups to develop problem-solving skills through a group discussion by asking friends who are not in conflict, or scaffolding provided by the teacher, the student can get out of the conflict. Students will utilize cognitive abilities in an attempt to seek justification, confirmation or verification of opinion. Thus, cognitive conflict is a condition of initial or stimulus in obtaining a balance (equilibrium) new. The level of balance (equilibrium) of this new higher level of balance (equilibrium) before.

Learning geography setup involving learners in building understanding geographic knowledge has been able to show excellent results. This is caused because the process of constructing knowledge of geography conducted jointly replace the process of learning the classical system with a lecture that the process of construction of knowledge conducted themselves according to what is captured by the students individually and in groups.

\section{CONCLUSIONS}

Based on the calculation of inferential statistics showed that learning outcomes of students who use rotation model 1 better than the results of student learning using rotation model 2. While student learning outcomes using rotation model 2 is better than rotation model 3. Rotation model 1 that begins with group work in problem-solving familiarizes students can challenge the ability of students and give satisfaction to discover new knowledge. Constructing knowledge together through group work enables students can express ideas, listen to the opinions of others and jointly build understanding. 


\section{ACKNOWLEDGMENT}

The author would like to thank the Dean of Social sciences and Law Faculty, Prof. Dr. Sarmini, M.Hum, for her contribution and attention.

\section{REFERENCES}

[1] A. E. Jailani \& A. Aishikin, "Developing soft skill in Advanced Technology Training Centre ( ADTEC): an analysis of comparison", Elixir Social Studies, 2011, vol 39, pp 4895-4904.

[2] A. P. School, July 2013, [Online], Available: http://aspirepublicschool.org/media/filer_public/2013/07/ 22/aspire-blended-learning-handbook-2013.pdf. [accessed: monday May 2014].

[3] A. Woolfolk, "Educational Psychology", Active Learning, 10nd Edition, Boston: Allyn and Bacon, 2009.

[4] C. M. Reigeluth, "Instructional-Design Theories and Models: An Overview of Their Current Status", New Jersey: Lawrence Erlbaum Associates, 1983.

[5] C.M. Reigeluth, "Instructional Theories in Action: Lessons Illustrating Selected Theories and Models", New Jersey: Lawrence Erlbaum Associates Publiser, 1987.

[6] D. Ismaimuza, "Effect Problem-Based Leraning Strategis toward Cognitive Conflict on Critical Thinking Skills, ' Journal of Matematics Education, 2010, vol 4(1), pp. 19.

[7] D. Marsh, "Blanded Learning, Cambridge", Cambridge: University Press, 2012.

[8] Jacobsen, “Methodes for Teaching”, New Jersey: Pearson Education, 2009.

[9] K. Moore, "'Effective Strategies Instructional, from Theory to Practice”, New York: Sage Publications Inc, 2005.

[10]R. Chiong \& J. Jovanovic, "Collaborative Learning in Online Study Groups: An Evolutionary Game Theory Perspective”, Journal of Information Technology Education, 2012, vol 11, pp 81-101.

[11]R. Phungsuk, C. Viriyavejakul, T. Ratanaolarn, "Development of a Problem-Based Learning Model Via Virtual Learning Environment”, Kasetsart Journal of Social Sciences , 2017, pp 1-10.

[12] using ADDIE Model, "Procedia - Social and Behavioral Sciences", 2015 , vol 195,pp 1803 - 1812.

[13] Y. H. Cho, H. Choi, J. Shin, H.C. Yu, Y. K. Kim, \& J.Y. Kim, "Review of Research on Online Learning Environments in Higher Education, Procedia - Social and Behavioral Sciences", 2015, vol 191, pp 2012 2017.

[14] Y. Miarso, "Sowing Seeds Technology Education", Jakarta: Prenada Media, 2004. 